\title{
Harmonization of Hemolysis Index in Clinical Chemistry Laboratory and Its Application as a Result Verification Tool
}

\author{
Sang Shin Pyo ${ }^{1}$, Hyun Su Nam ${ }^{1}$, Young Jong Cha ${ }^{1}$, Seungkwan Lee ${ }^{2}$, Hae Kyung Lee ${ }^{1}$ \\ ${ }^{1}$ Department of Laboratory Medicine, Uijeongbu St. Mary's Hospital, The Catholic University of Korea, Uijeongbu, Korea \\ ${ }^{2}$ Department of Health and Environmental Science, College of Health Science, KoreaUniversity, Seoul, Korea
}

\section{화학검사 결과의 검증을 위한 용혈 지수 일치화 도구 개발}

\author{
표상신 ${ }^{1}$, 남현수 $^{1}$, 차영종 $^{1}$, 이승관 ${ }^{2}$, 이혜경 ${ }^{1}$ \\ ${ }^{1}$ 가톨릭대학교 의정부성모병원 진단검사의학과, ${ }^{2}$ 고려대학교 보건과학대 보건환경융합과학부
}

\begin{abstract}
The hemolysis index (HI) is semi-quantitative marker for hemolysis. Because the characteristics of the $\mathrm{HI}$ vary from one commercial platform to another, no standardization or harmonization of the $\mathrm{HI}$ is currently available. Specimens $(\mathrm{N}=40)$ randomly selected from clinical patients were artificially hemolyzed in vitro. The serum of the specimens was then diluted with a $20 \mathrm{mg} / \mathrm{dL}$ difference between $0 \sim 300 \mathrm{mg} / \mathrm{dL}$ based on serum hemoglobin measured using the XE-2100 hematology automation equipment (Sysmex, Japan). Diluted serum was measured using the Hitachi-7600 biochemical automation equipment (Hitachi, Japan) to differentiate between $\mathrm{HI}$ and serum hemoglobin. The data showed linearity between $\mathrm{HI}$ and serum hemoglobin and that $\mathrm{HI} 1$ contained approximately $20 \mathrm{mg} / \mathrm{dL}$ of serum hemoglobin. To determine the blood rejection threshold, the HI was divided into three groups: $\mathrm{HI} 0 \sim 1, \mathrm{HI} 4 \sim 6, \mathrm{HI}$ 9 15. After another batch of clinical specimens $(\mathrm{N}=40)$ was measured using a Hitachi-7600 (Hitachi, Japan), each specimen was moved forward and backward with the piston of the syringe to induce an artificial in vitro hemolysis, then measured again with a Hitachi-7600 (Hitachi, Japan). The percentage difference between the three groups was analyzed by ANOVA or the Kruskal-Wallis test. In the post-test, there were significant differences between the HI 0 1 and the HI 5 6: Glucose, creatinine, total protein, AST, direct bilirubin, uric acid, phosphorus, triglyceride, LDH, CPK, Magnesium, and potassium levels. Because many clinical tests differed significantly, the threshold for hemolysis could be appropriate for HI 5 (serum hemoglobin $100 \mathrm{mg} / \mathrm{dL}$ ).
\end{abstract}

Key words: Hemolysis index, Preanalytical variability, Standardization

This is an Open Access article distributed under the terms of the Creative Commons Attribution Non-Commercial License (http://creativecommons.org/licenses/by-nc/4.0) which permits unrestricted non-commercial use, distribution, and reproduction in any medium, provided the original work is properly cited.

Copyright ( 2017 The Korean Society for Clinical Laboratory Science. All rights reserved.
Corresponding author: Hae Kyung Lee Department of Laboratory Medicine, Uijeongbu St. Mary's Hospital, College of Medicine, The Catholic University of Korea, 271 Cheonbo-ro, Uijeongbu 11765, Korea

Tel: 82-31-820-3159

Fax: 82-31-847-6266

E-mail: hkl@catholic.ac.kr

Received: August 1, 2017

Revised 1 $1^{\text {st: }}$ August 31, 2017

Revised $2^{\text {nd. }}$ : September 18, 2017

Accepted: September 20, 2017

\section{서 론}

국내외 임상화학 검사실에서 부적합 검체의 주요한 원인 중 하나로 체외 용혈(in vitro hemolysis)이 있다[1-3]. 용혈 간섭 (hemolysis interference)은 임상화학 검사에 있어서 특정 검 사 종목에서 증가 또는 감소되어 영향을 미치는 것으로 알려져 있다[4]. 그 중 임상에서 특히 문제가 되는 것은 포타슘 검사로
높은 포타슘은 심실빈맥, 심실조기 수축, 심실세동 등을 야기한 다[5]. 용혈로 인한 검사 수치의 증가 또는 감소는 실제 환자의 상태를 반영하는 것이 아니므로 임상에 재채혈을 요구하기도 한다. 이로 인해 치료지연과 환자불만이 초래된다.

용혈된 검체는 혈청 헤모글로빈 $10 ~ 30 \mathrm{mg} / \mathrm{dL}$ 정도인 경우 연한 빨간색으로 눈에 띄기 시작한다[6]. 용혈을 판단할 때 혈청 이나 혈장 가운데 빨간색을 통해 눈으로 또는 용혈 지수로 통해 
판단을 한다. 그러나 용혈 지수는 각 장비마다 회사별로 각각의 측정 공식과 임상검사실의 측정방법이 다르기 때문에 효율적으로 사용되지 못하고 있었다[7]. 임상검사가 표준화 (standardization) 또는 일치화(harmonization)되어 있지 않으면, 같은 검체로도 방법마다 다른 결과를 보이게 된다. CLSI guide line (C56-A)에 서 일치화는 다른 검사실끼리 결과를 교환할 수 있도록 최소한 결과를 변환하거나 결과를 균일하게 하는 과정을 인식, 이해, 설 명하는 과정을 말한다. 일치화를 다시 설명하자면 측정 절차, 적 용된 단위 또는 기준 간격 및 측정 시기 또는 장소에 관계없이 동 일한 결과 및 동일한 해석을 할 수 있는 능력을 의미한다[8]. 표 준화와 일치화의 주요한 개념적 차이는 표준화에는 표준측정방 법 또는 일차표준물질이 존재할 경우이고 일치화는 표준측정방 법 또는 일차표준물질이 존재하지 않을 경우를 말한다. 이에 본 연구는 용혈지수와 혈청 헤모글로빈의 관계를 평가하고 실무에 서 효율적으로 사용하기 위한 정량적인 용혈의 기준값 (threshold) 설정하고 용혈 지수의 일치화를 통한 결과검증 도 구로써의 모델을 제시하고자 한다.

\section{재료 및 방법}

\section{1. 재료 및 방법}

2016년 10월 첫째 주부터 2016년 10월 둘째 주까지 외래에 방문한 환자 검체 중 냉장 보관되어 있는 임상 검체에서 무작위 로 뽑은 Serum Separation Tube (SST) 40개의 검체 표본을 $-35^{\circ} \mathrm{C}$ 냉장고에 12 시간 보관한 후 이를 충분히 녹이면 인위적 인 체외 용혈이 되어 진다. 그리고 30 분간 원심분리 $(2,500 \mathrm{G})$ 를 통해 혈병인 하층은 제거하고 상층인 혈청을 분리한다. 아직 혈 청 안에 남아있는 적혈구를 완전히 제거하기 위해 3차 증류수로 희석하여 삼투압 충격(osmotic shock)을 준다. 60분간 원심분 리 $(2,500 \mathrm{G})$ 를 통해 적혈구가 완전히 제거되도록 한다. 혈액학 자동 분석 장비인 XE-2100 (Sysmex, Kobe, Japan)을 이용하 여 혈청 헤모글로빈을 비시안화 물질인 sodium lauryl sulfate (SLS)로 측정한다[9-11]. 이 때 검사의 정확도를 위해 측정 가능 범위(analytical measurement range, AMR) 내의 값으로 한 다. 각각의 검체를 $0 \sim 300 \mathrm{mg} / \mathrm{dL}$ 사이에서 $20 \mathrm{mg} / \mathrm{dL}$ 차이가 나도록 희석하였다. 희석에 이용한 공식은 다음과 같다.

$$
\begin{gathered}
\mathrm{M}(\text { 용액의 농도 }) \times \mathrm{V}(\text { 용액의 양 }) \\
=\mathrm{M}^{\prime}(\text { 희석 용액의 농도 }) \times \mathrm{V}^{\prime}(\text { 희석 용액의 양 })
\end{gathered}
$$

Table 1 과 같이 희석 공식을 이용하여 40 개의 검체를 원하는
농도로 희석한다. 그런 다음 생화학 자동화장비인 Hitachi-7600 (Hitachi, Tokyo, Japan)에서 각각의 용혈 지수를 측정한다 (Figure 1).

Lippi 등[12,13]의 연구와 Petinos [14]의 RCPAQAP (Royal College of Pathologists of Australasia Quality Assurance Programs) survey를 근거로 용혈 지수를 3개의 group으로 나 눈다: 용혈 지수 0 1, 용혈지수 4 6, 용혈 지수 9 15. 2016 년 10월 첫째 주부터 2016년 10월 둘째 주까지 외래에 방문한 환자 검체 중 냉장 보관되어 있는 임상 검체에서 무작위로 뽑은 40개의 Serum Separating Tube (SST) 검체 표본을 생화학 자 동화 장비인 Hitachi-7600 (Hitachi, Japan)에서 임상 검사 종 목들을 시행한다. 그런 다음 SST 검체에서 겔을 제거하고 다시 혈청과 혈병을 잘 섞은 다음 $22 \mathrm{G}$ 주사기의 피스톤을 앞- 뒤로 움직여 주사기 바늘로 인위적 체외 용혈을 시킨다. 각각 10 번, 20 번, 30 번을 움직여 인위적으로 용혈시킨 검체를 5 분간 원심 분리 $(2,500 \mathrm{G})$ 를 한 후 각각을 또 다시 Hitachi-7600 (Hitachi,

Table 1. Dilution method of serum hemoglobin

\begin{tabular}{cccccc}
\hline \multicolumn{5}{c}{ Examples of dilution in 5 clinical specimens } \\
\hline $\begin{array}{c}\mathrm{M} \\
(\mathrm{g} / \mathrm{dL})\end{array}$ & $\begin{array}{c}\mathrm{V} \\
(\mathrm{mL})\end{array}$ & $\begin{array}{c}\mathrm{M}^{\prime} \\
(\mathrm{g} / \mathrm{dL})\end{array}$ & $\begin{array}{c}\mathrm{V}^{\prime}(\mathrm{V}+\mathrm{D} . \mathrm{W} .) \\
(\mathrm{mL})\end{array}$ & $\begin{array}{c}\mathrm{V} \\
(\mathrm{mL})\end{array}$ & $\begin{array}{c}\mathrm{D} . \mathrm{W} . \\
(\mathrm{mL})\end{array}$ \\
\hline 3.1 & 1.29 & 1 & 4 & 1.290 & 2.710 \\
4.1 & 0.976 & 1 & 4 & 0.976 & 3.024 \\
3.9 & 1.026 & 1 & 4 & 1.026 & 2.974 \\
3.8 & 1.053 & 1 & 4 & 1.053 & 2.947 \\
3 & 1.333 & 1 & 4 & 1.333 & 2.667 \\
\hline \multicolumn{5}{c}{ Detailed dilution method } \\
\hline 1 & 0.02 & 0.02 & 1 & 0.02 & 0.98 \\
1 & 0.04 & 0.04 & 1 & 0.04 & 0.96 \\
1 & 0.06 & 0.06 & 1 & 0.06 & 0.94 \\
1 & 0.08 & 0.08 & 1 & 0.08 & 0.92 \\
1 & 0.10 & 0.10 & 1 & 0.10 & 0.90 \\
1 & 0.12 & 0.12 & 1 & 0.12 & 0.88 \\
1 & 0.14 & 0.14 & 1 & 0.14 & 0.86 \\
1 & 0.16 & 0.16 & 1 & 0.16 & 0.84 \\
1 & 0.18 & 0.18 & 1 & 0.18 & 0.82 \\
1 & 0.20 & 0.2 & 1 & 0.20 & 0.80 \\
1 & 0.22 & 0.22 & 1 & 0.22 & 0.78 \\
1 & 0.24 & 0.24 & 1 & 0.24 & 0.76 \\
1 & 0.26 & 0.26 & 1 & 0.26 & 0.74 \\
1 & 0.28 & 0.28 & 1 & 0.28 & 0.72 \\
1 & 0.30 & 0.30 & 1 & 0.30 & 0.70 \\
\hline
\end{tabular}

MV, M'V': Dilution Formula, Concentration (start) $\times$ Volume (start) $=$ Concentration (final) $\times$ Volume $($ final); $M(g / d L)$, Serum hemoglobin measured with XE-2100 (Sysmex, Kobe, Japan); V $(\mathrm{mL})$, Volume of serum hemoglobin required for target dilution; $M^{\prime}(\mathrm{g} / \mathrm{dL})$, Target concentration of the diluted solution; $\mathrm{V}^{\prime}(\mathrm{mL})$, Target volume of the diluted solution. 


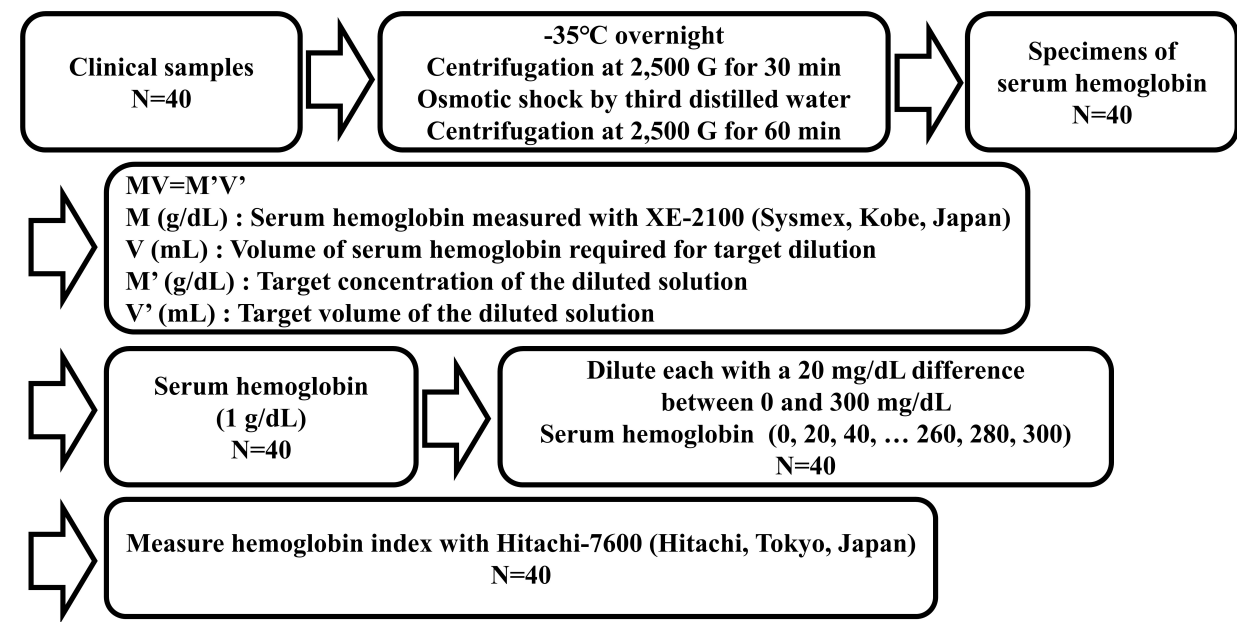

Figure 1. Flow chart of dilution for quantitative evaluation of hemoglobin index.
Japan)에서 검사를 한다. 이때 피스톤의 움직임에 따라 일정하 게 용혈되지 않으므로 피스톤을 움직임에 따라 용혈 지수가 각 각의 그룹에서 정한 범위에 들어가는지 용혈 지수만 검사하여 확인한 후 생화학 검사를 시행한다. 각각의 종목을 백분율 차이 (percentage difference)를 기준으로 통계 분석을 한다. 백분 율 차이는 다음과 같다.

$$
\text { 백분율차이 }=\frac{\text { 측정값-기준값 }}{\left(\frac{\text { 측정값 }+ \text { 기준값 }}{2}\right)} \times 100
$$

\section{2. 통계 분석}

각 그룹의 임상 검사종목의 백분율 차이를 정규성 검정과 등 분산 검정을 실시한다. 정규성 검정은 Shapiro-Wilk test를 실 시하여 유의수준이 $p<0.05$ 일 경우 Kruskal-Wallis test를 실 시하고, $p>0.05$ 이면 Levene's 등분산 검정하여 유의수준이 $p$ $<0.05$ 일 경우 Welch 또는 Brown-Forsythe test 실시하고, $p>0.05$ 이면 ANOVA test 실시한다. ANOVA의 사후검정은 Bonferroni으로 하고 유의수준은 $p<0.05$ 으로 한다. Kruskal-wallis test의 사후검정은 Mann-Whitney test하고 다중비교로 인한 문제로 인해 유의 수준은 $p<0.017$ (0.05/검 정의 횟수)로 한다. 통계 분석은 Windows SPSS 20.0 (IBM, Armonk, USA) 또는 R 3.4.1로 하였다.

\section{결 과}

\section{1. 용혈 지수와 혈청 헤모글로빈의 선형성}

용혈 지수와 혈청 헤모글로빈은 선형성을 보였으며 대략 용 혈 지수 1 은 혈청 헤모글로빈 대략 $20 \mathrm{mg} / \mathrm{dL}$ 정도였다. 혈청 헤

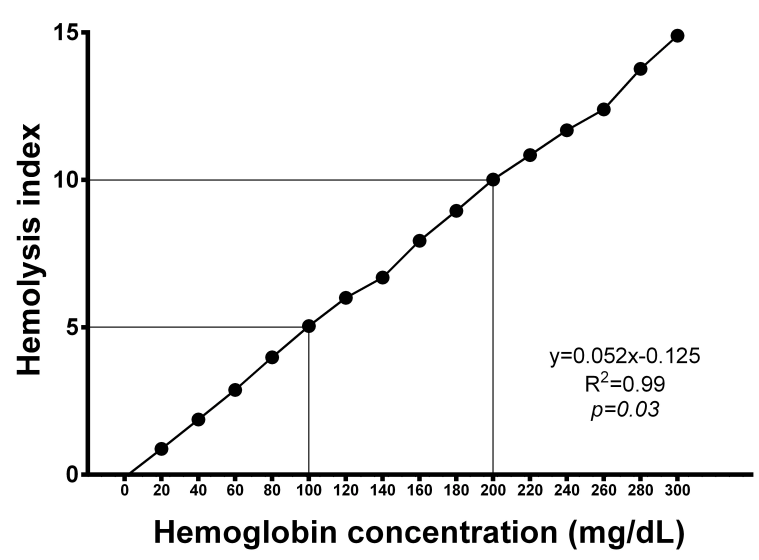

Figure 2. Linearity between hemoglobin concentration and hemolysis index.

모글로빈 $100 \mathrm{mg} / \mathrm{dL}$ 일때 용혈 지수는 5.08 이였고, 혈청 헤모 글로빈 $200 \mathrm{mg} / \mathrm{dL}$ 의 용혈 지수는 10.28이였다(Figure 2).

\section{2. 용혈 거절을 위한 기준값을 설정}

용혈 지수를 용혈 지수 0 1, 용혈지수 4 6, 용혈 지수 9 15으로 세 그룹으로 나누고[12-14] 세 그룹에 따른 임상 검사 종목의 백분율 차이를 ANOVA 또는 Kruskal-Wallis test 분석 하였다. 사후 검정에서 용혈 지수 0 1인 그룹과 용혈지수 9 15인 그룹 사이에서 유의한 차이가 나는 종목들은 albumin, alanine aminotransferase (ALT), alkaline phosphatase (ALP), total bilirubin, calcium, amylase이다. 용혈 지수 0 1 인 그룹과 용혈지수 4 6인 그룹 사이에서 유의한 차이가 나는 종목들은 glucose, creatinine, total protein, aspartate aminotransferase (AST), direct bilirubin, uric acid, phosphorus, triglyceride, lactate dehydrogenase (LDH), creatine phosphokinase (CPK), magnesium, potassiumol 
다 $(p<0.001$, Table 2). 위의 종목 중 용혈에 따른 백분율 차이 가 증가하는 종목은 creatinine, total protein, AST, phosphorus, LDH, CPK, magnesium, potassium이고, 백분 율 차이가 감소하는 종목은 glucose, direct bilirubin, uric acid, triglyceride이다. 반면에 blood urea nitrogen (BUN), total cholesterol, gamma-glutamyltransferase (GGT) 종목 만이 통계적으로 유의한 차이가 관찰되지 않았다 $(p>0.05$, Table 2).

\section{3. 용혈 지수와 백분율 차이의 산포도}

용혈 지수 0 1인 그룹과 용혈지수 4 6인 그룹 사이에서 유 의한 차이가 나는 종목들 가운데 회귀계수가 큰 종목들은 glucose가 -7.38, AST가 3.93, phosphorus가 2.97, LDH가 $7.55, \mathrm{CPK}$ 가 2.5, 그리고 potassium이 3.11이었고, 결정계수 $\left(\mathrm{R}^{2}\right)$ 가 큰 종목들은 glucose가 0.63, total protein이 0.92, AST 가 $0.79, \mathrm{LDH}$ 가 0.86 , 그리고 magnesium이 0.60 이었다 (Figure 3).

\section{고 찰}

근거 중심의 진단검사는 체계적 연구를 통한 현 시점까지 최 선의 과학적인 근거와 임상적 경험을 양심적이고 현명하게 이 용하는 전문성이 결합하여 개별 환자에 대한 맞춤 적용을 결정 하는 것이며 이것들이 서로 상호 통합으로 이루어지는 의료를 의미한다[15]. 근거 기반 의학에서 최근에는 근거 기반 간호, 근 거 기반 보건의료, 근거중심 정신보건 등으로 적용분야가 넓혀 져 왔다. 이런 시대적 흐름에 따라 심혈관 질환, 당뇨병, 대사증 후군과 같은 질병에 정확한 진단기준과 적절한 치료를 위해서 표준화와 검사실 데이터 관리의 필요성이 강조되고 있다. IFCC (International Federation of Clinical Chemistry), ISO (International Organization for Standardization), CLSI (Clinical and Laboratory Standards Institute), AACB (Australasian Association of Clinical Biochemists)에서 표준 화 또는 일치화를 위해 노력하고 있지만 용혈 지수는 현재 임상 화학 장비에서 일치화 되어 있지 않고 있다. 이에 혈청 헤모글로 빈에 대한 용혈지수를 평가하고 그 기준값을 설정하여 근거중

Table 2. Analysis of variance of percentage difference among three groups (hemolysis index $0 \sim 1$, hemolysis index $4 \sim 6$, hemolysis index $9 \sim 15)$

\begin{tabular}{|c|c|c|c|c|c|}
\hline \multirow{2}{*}{ Variable } & \multicolumn{5}{|c|}{$\mathrm{HI}$ groups } \\
\hline & Allowable CV ${ }^{\S}(\%)$ & $0-1 \quad(N=40)$ & $4-6(N=40)$ & $9-15(N=40)$ & $p$-value ${ }^{\ddagger}$ \\
\hline Glucose (mg/dL) & 5 & $0 \pm 0$ & $-53.2 \pm 22.0^{\star}$ & $-91.9 \pm 36.3^{\dagger}$ & $<0.001$ \\
\hline BUN (mg/dL) & 5 & $0 \pm 0$ & $-2.6 \pm 25.8$ & $-2.4 \pm 25.8$ & 0.83 \\
\hline Creatinine (mg/dL) & 7 & $0 \pm 0$ & $9.4 \pm 10.4^{*}$ & $6.7 \pm 10.4^{\dagger}$ & $<0.001$ \\
\hline Total protein $(\mathrm{g} / \mathrm{dL})$ & 10 & $0 \pm 0$ & $2.4 \pm 1.0^{*}$ & $6.5 \pm 1.5^{\dagger}$ & $<0.001$ \\
\hline Albumin $(\mathrm{g} / \mathrm{dL})$ & 5 & $0 \pm 0$ & $-0.2 \pm 1.4$ & $0.7 \pm 1.4^{\dagger}$ & $<0.001$ \\
\hline Total cholesterol (mg/dL) & 5 & $0 \pm 0$ & $-0.1 \pm 1.2$ & $-0.1 \pm 1.6$ & 0.95 \\
\hline AST $(I U / L)$ & 7 & $0 \pm 0$ & $21.4 \pm 8.5^{\star}$ & $46.7 \pm 14.6^{\dagger}$ & $<0.001$ \\
\hline $\operatorname{ALT}(I U / L)$ & 7 & $0 \pm 0$ & $0.5 \pm 8.3$ & $7.5 \pm 8.3^{\dagger}$ & $<0.001$ \\
\hline $\operatorname{ALP}(I U / L)$ & 5 & $0 \pm 0$ & $-1.0 \pm 2.8$ & $-3.9 \pm 5.4^{\dagger}$ & $<0.001$ \\
\hline Total bilirubin (mg/dL) & 5 & $0 \pm 0$ & $-1.5 \pm 3.9$ & $2.8 \pm 4.4^{\dagger}$ & $<0.001$ \\
\hline Direct bilirubin (mg/dL) & 10 & $0 \pm 0$ & $-19.2 \pm 10.6^{*}$ & $-17.0 \pm 11.6^{\dagger}$ & $<0.001$ \\
\hline GGT (IU/L) & 7 & $0 \pm 0$ & $1.9 \pm 5.1$ & $0.9 \pm 5.1$ & 0.14 \\
\hline Uric acid (mg/dL) & 5 & $0 \pm 0$ & $-1.8 \pm 2.0^{*}$ & $-3.5 \pm 2.3^{\dagger}$ & $<0.001$ \\
\hline Calcium (mg/dL) & 5 & $0 \pm 0$ & $1.3 \pm 2.8$ & $2.8 \pm 3.7^{\dagger}$ & $<0.001$ \\
\hline Phosphorus (mg/dL) & 5 & $0 \pm 0$ & $20.4 \pm 18.6^{*}$ & $33.2 \pm 31.3^{\dagger}$ & $<0.001$ \\
\hline Triglyceride (mg/dL) & 5 & $0 \pm 0$ & $-2.4 \pm 2.2^{\star}$ & $-3.5 \pm 1.6^{\dagger}$ & $<0.001$ \\
\hline $\mathrm{LDH}(\mathrm{IU} / \mathrm{L})$ & 5 & $0 \pm 0$ & $53.5 \pm 13.3^{*}$ & $84.8 \pm 36.7^{\dagger}$ & $<0.001$ \\
\hline CPK (IU/L) & 5 & $0 \pm 0$ & $17.3 \pm 15.8^{*}$ & $30.4 \pm 17.7^{\dagger}$ & $<0.001$ \\
\hline Magnesium (mg/dL) & 10 & $0 \pm 0$ & $1.0 \pm 0.8^{\star}$ & $1.8 \pm 0.8^{\dagger}$ & $<0.001$ \\
\hline Amylase $(I U / L)$ & 5 & $0 \pm 0$ & $-1.2 \pm 2.8$ & $-3.1 \pm 2.5^{\dagger}$ & $<0.001$ \\
\hline Potassium $(\mathrm{mmol} / \mathrm{L})$ & 5 & $0 \pm 0$ & $20.2 \pm 14.2^{*}$ & $34.9 \pm 23.7^{\dagger}$ & $<0.001$ \\
\hline
\end{tabular}

Values are presented as mean \pm standard deviation by percentage difference.

${ }^{*} p<0.05$ [HI $0 \sim 1$ group] vs [HI 4 6 group], ${ }^{\dagger} p<0.05$ [HI 0 1 group] vs [HI 9 15 group] (post hoc test by bonferroni correction or Mann-Whitney test). ${ }^{\ddagger}$ Calculated by ANOVA or Kruskal-Wallis test. ${ }^{\S}$ Coefficient of variation $(\mathrm{CV})=\frac{\text { mean }}{\text { standard deviation }} \times 100$.

Abbreviations: HI, hemolysis index; BUN, blood urea nitrogen; AST, Aspartate Aminotransferase; ALT, Alanine Aminotransferase; ALP, Alkaline Phosphatase; GGT, Gamma-Glutamyltransferase; LDH, Lactate Dehydrogenase; CPK, Creatine phosphokinase. 

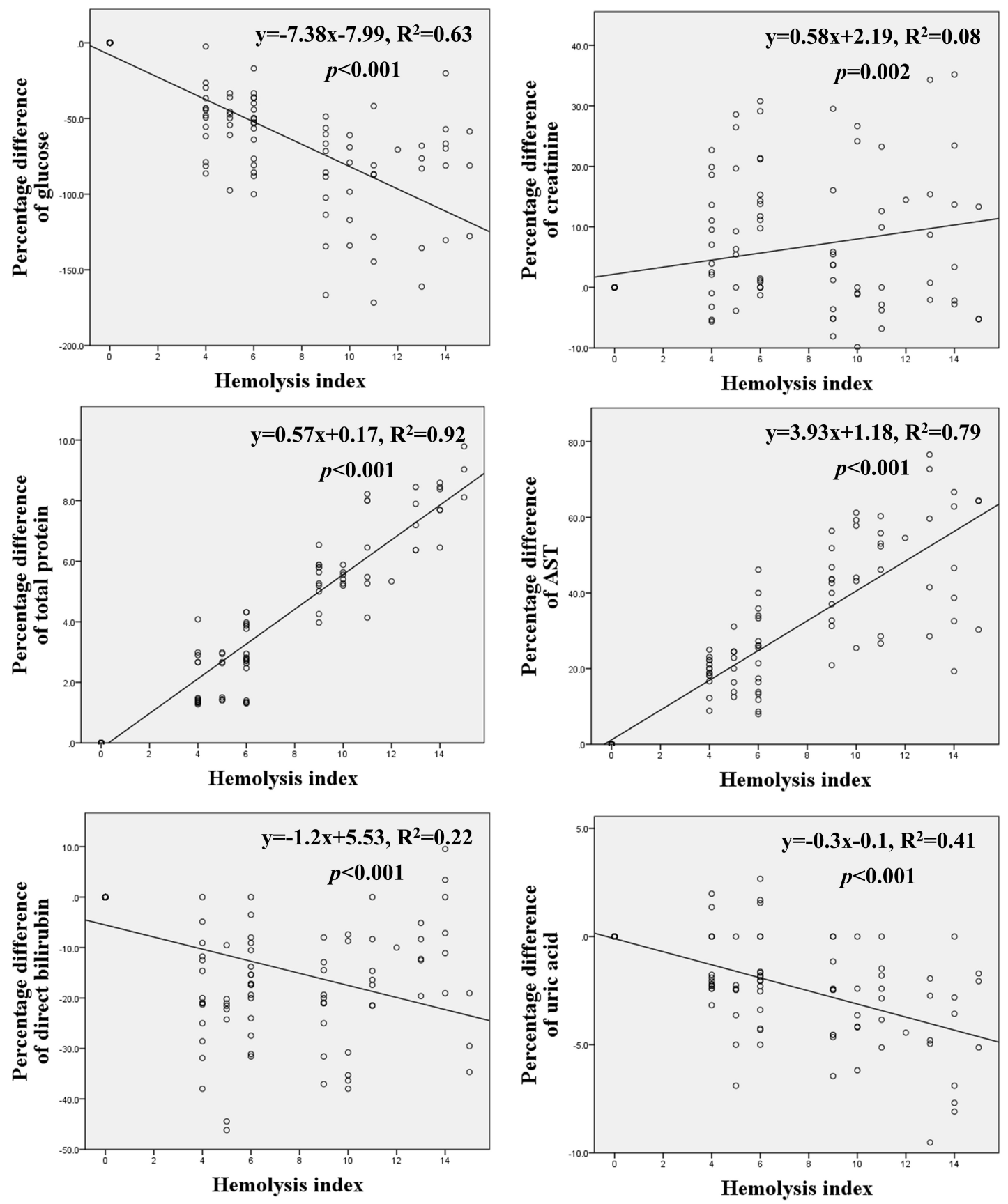

Figure 3. Scatter plot of percentage difference and hemolysis index for clinical test showing statistically significant differences between the group with hemolysis index $0 \sim 1$ and the group with hemolysis index 4 6. Abbreviations: See Table 2 .

심의 실무에 효율적으로 사용되고 용혈 지수에 대한 일치화의 첫 걸음으로 시도된 본 연구는 그 의미가 크다.

Frank 등[16]의 연구에서 용혈 지수와 헤모글로빈은 선형성 을 보였다. 본 연구에서도 혈청 헤모글로빈과 용혈 지수는 선형 성을 가졌고 혈청 헤모글로빈 $100 \mathrm{mg} / \mathrm{dL}$ 일때 용혈 지수는 5.08 이였고, 혈청 헤모글로빈 $200 \mathrm{mg} / \mathrm{dL}$ 의 용혈 지수는 10.28 이였다(Figure 2). 체외 용혈에 있어서 주사기 이외에 채혈 기
술, 지혈대의 적용시간, 채혈 위치, 주사기의 압력, 진공 채혈과 주사기 채혈, 그리고 게이지 굵기 등과 같은 다양한 원인이 있겠 지만[17,18] 주로 주사기에 의한 용혈이 많기 때문에 주사기 피 스톤의 횟수를 통한 용혈을 기준으로 잡았다[19,20]. 용혈 지수 를 용혈 지수 0 1, 용혈지수 4 6 (80 120 mg/dL), 용혈 지수 9 15 (180 300 mg/dL) 으로 세 그룹으로 나눠 분석하였다. 세 그룹으로 나눠 분석한 이유는 첫째, Lippi 등[12,13]의 연구 

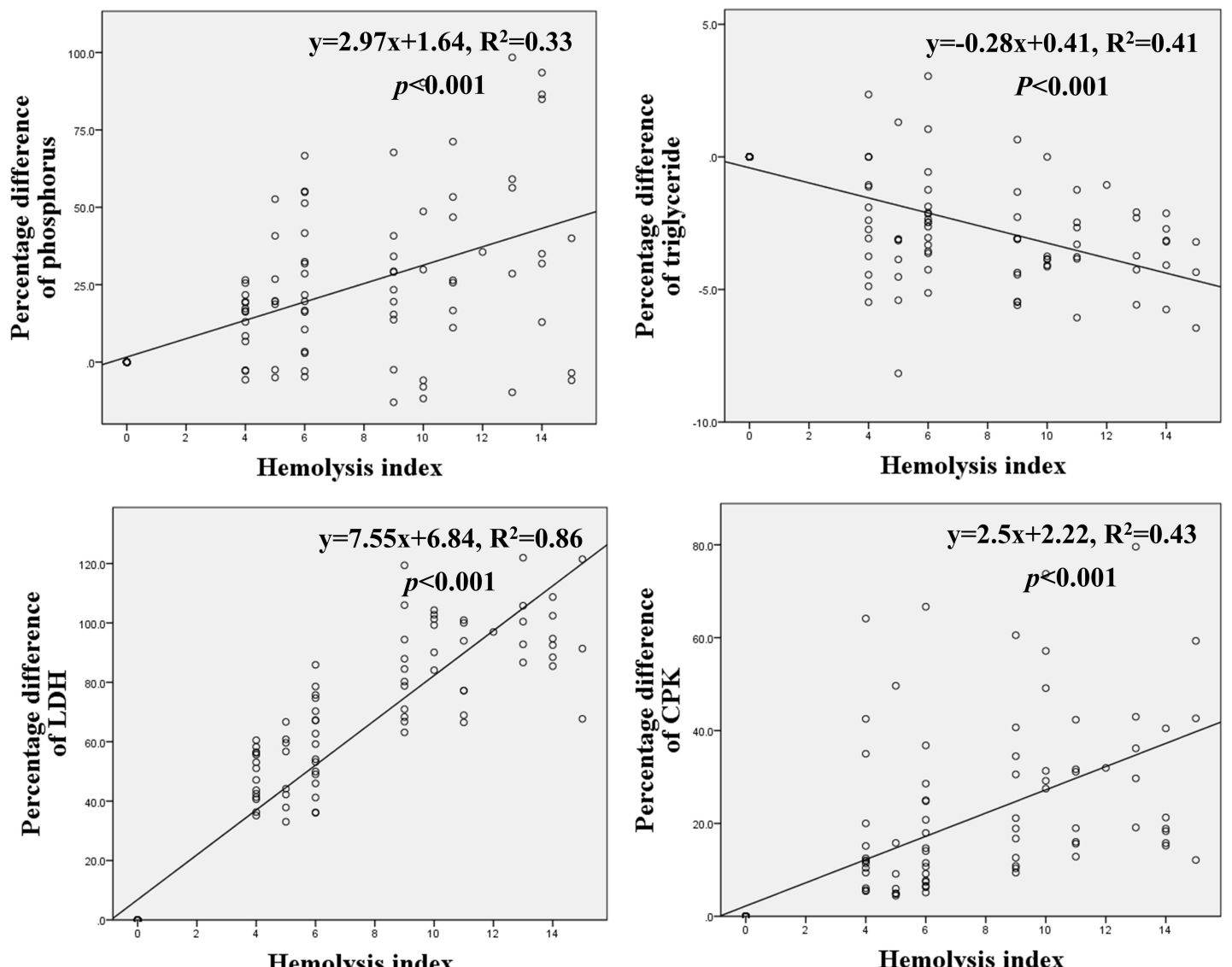

ysis index
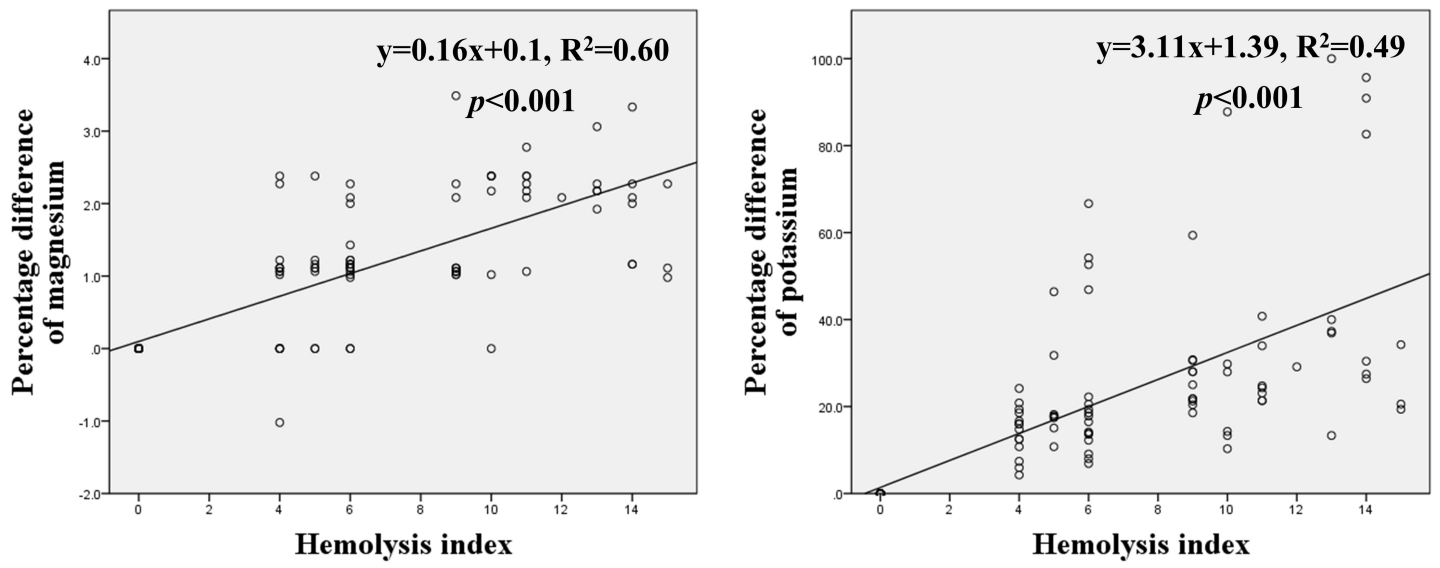

Figure 3. Continued.

에서 용혈로 인한 혈청 헤모글로빈 농도가 $16 \mathrm{mg} / \mathrm{dL}$ 에서부터 AST, creatine kinase, gamma-GTT, LDH, potassium, Sodium 종목들은 통계적으로 유의한 차이를 보이고 혈청 헤모 글로빈 농도가 증가함에 따라 다른 임상 종목들도 통계적으로 차이를 보이기 시작하였다. 특히 혈청 헤모글로빈 농도 60 $130 \mathrm{mg} / \mathrm{dL}$ 구간에서 AST, creatine kinase, gamma-GTT, $\mathrm{LDH}$, potassium, sodium 이외에 통계적으로 유의한 임상 종 목들이 증가하였다. 그러므로 용혈지수 4 6 (80 120 mg/dL)
를 기준점으로 설정하여 많은 임상 검사 종목에 대해 효율적으 로 용혈에 대한 평가를 할 수 있다고 판단된다. 둘째, Petinos [14]의 최근 일치화에 활발한 $\mathrm{AACB}$ 의 RCPAQAP survey 에 따 르면 $100 \mathrm{mg} / \mathrm{dL}$ 에서 $500 \mathrm{mg} / \mathrm{dL}$ 사이에서 용혈의 기준값을 정 한 기관이 약 48\%이였다[14]. 그러므로 용혈지수 4 6 (80 $120 \mathrm{mg} / \mathrm{dL}$ )의 상위 구간으로 용혈 지수 9 15 (180 300 $\mathrm{mg} / \mathrm{dL}$ )을 기준을 잡았다. CLSI 가이드라인 C56-A에서 용혈은 $50 \mathrm{mg} / \mathrm{dL}$ 에서 유의한 차이가 보인다고 기술되어 있다. 
$\mathrm{RCPAQAP}$ survey에서 $50 \mathrm{mg} / \mathrm{dL}$ 을 기준값으로 설정한 기관은 91개의 기관 중에서 단 한 기관 밖에 없었다. 용혈에 대한 기준 값에 대한 기준점은 향후 논의가 필요하다고 생각되고 후속 연 구에서 연속형 변수로 세밀한 분석이 필요하다 생각된다.

용혈 지수 $0 \sim 1$ 인 그룹과 용혈지수 5 6인 그룹과 유의한 차 이가 나는 종목들은 glucose, creatinine, total protein, AST, direct bilirubin, uric acid, phosphorus, triglyceride, lactate dehydrogenase (LDH), creatine phosphokinase (CPK), magnesium이다(Figure 3). 용혈 지수 0-1인 그룹과 용혈지수 9 15인 그룹과 유의한 차이가 나는 종목들 albumin, GPT, alkaline phosphatase (ALP), total bilirubin, calcium이다 (Table 2). 본 실험에서 많은 임상 검사 종목들이 용혈지수 5에 서 유의한 차이를 보이기 시작하므로 임상화학 검사의 용혈지 수 $5(100 \mathrm{mg} / \mathrm{dL})$ 에서 판정기준치를 정하는 것이 통계적으로 판단된다. 그러나 용혈에 영향이 큰 종목들 대한 정확한 데이터 가 필요하다면 용혈지수의 판정기준치을 낮추는 것이 고려된 다. 외국의 많은 기관이 혈청 헤모글로빈에 대한 용혈 기준이 일 관성 없이 진행되고 있으나[21], 최근 일치화를 위한 각 검사종 목에 따라 용혈의 영향 정도를 반영한 용혈 지수의 각각의 허용 범위를 설정하고 이를 고려한 보고를 하였다[22,23]. 또한 용혈 된 검체의 용혈 정도를 반영하여 포타슘 같은 특정 검사종목의 수치를 용혈 지수를 이용한 보정을 생각해 볼 수 있겠다[24]. 이 는 응급실 같이 체외 용혈로 인한 재채혈이 힘든 곳에서 고려해 볼 수 있다.

나중에 데이터가 쌍이면서 합의된 일치화 방법이 고안되고 그것으로 용혈 지수를 평가할 수 있다[25]. 그 중 하나의 예로 각 검사실에서 분기 또는 반기에 임상화학 자동화 장비에서의 용 혈 지수를 합의된 평가 그리고 검증하여 종합한 결과를 바탕으
로 임상화학 각 장비에서의 용혈지수에 대한 계산 공식의 요인 값를 설정하여 용혈지수 범위를 조정할 수 있다. Hitachi-7600 (Hitachi, Japan)에서의 용혈 지수는 다음과 같다.

$$
\text { 용혈지수 }=\frac{1}{\mathrm{~A}}(\triangle \mathrm{EH}-\mathrm{B} \times \triangle \mathrm{EL})
$$

$\triangle \mathrm{EH}$ 는 600/570에서의 흡광도를 측정한 값이고 용혈과 관 계되고, $\triangle \mathrm{EL}$ 은 700/660에서의 흡광도를 측정한 값이고 고지 혈증과 관계되고, 그리고 $\triangle \mathrm{EI}$ 는 505/480에서의 흡광도를 측 정한 값이고 고빌리루빈혈증과 관계된다. $\mathrm{A}$ 는 제조사에서 정하 는 수정 가능한 요인값이며 $\mathrm{B}$ 는 수정 금지 요인값이다. 용혈 지 수 공식에서 $\mathrm{B} \times \triangle \mathrm{EL}$ 는 고지혈증에 대한 보정 역할을 한다. 그 러므로 수정 가능한 요인인 $\mathrm{A}$ 를 수정하여 범위를 조정할 수 있 다. 이와같은 방법으로 혈청 헤모글로빈의 농도에 따른 용혈 지 수의 범위를 일치화가 가능하다. 다른 플랫폼의 장비도 위와 같 은 방식으로 용혈 지수의 범위가 변경 가능하다. 이에 따라 용혈 지수를 임상에서 쉽게 참고하고 활용할 수 있도록 용혈 지수의 범위를 상대적으로 변경할 수 있겠다. 용혈 지수의 범위를 일치 화시켜 실무에 활용하는 것이 용혈 지수의 일치화의 첫걸음이 라 생각한다.

본 연구를 통해 total laboratory automation (TLA) system 에서 panic check와 delta check와 더불어 인터페이스 결과검 증도구로써 용혈 지수를 사용하여 샘플에 대한 용혈을 정량적 으로 평가하여 자동화할 수 있게 할 수 있다. 용혈을 직접 눈으로 확인하지 않고 용혈 지수를 통해 정량적으로 분석하고 검체의 무결성을 평가하여 검사 결과를 보고하거나 재채혈을 요구할 수 있다. 이에 laboratory information system (LIS)에 대한 다 양한 알고리즘을 설계하여 데이터 과학화하여 실무에 활용할

\section{Clinical outcomes}

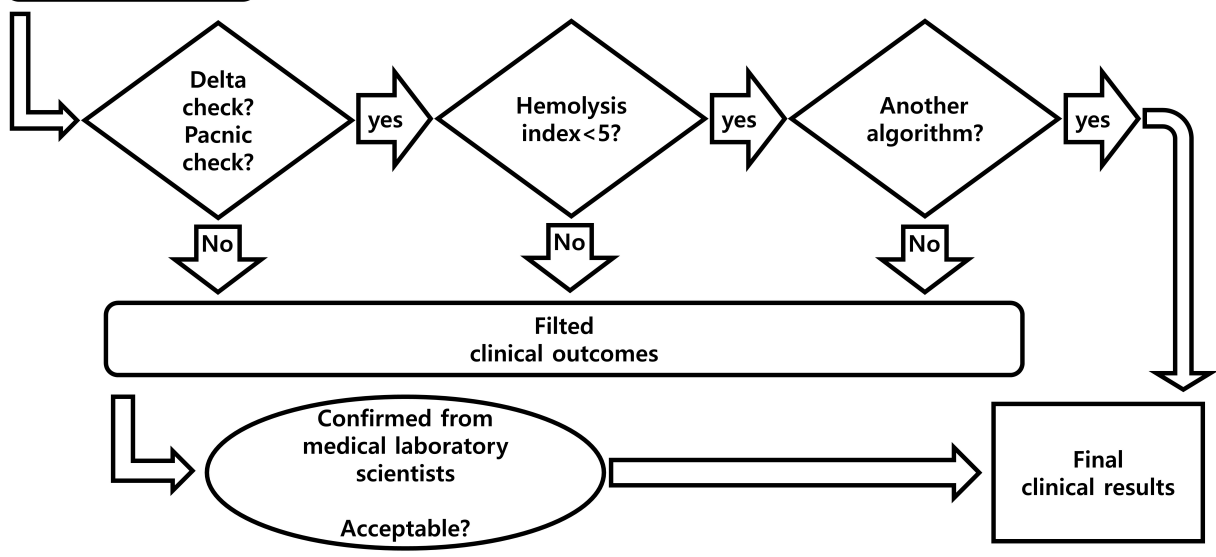

Figure 4. Design of various algorithms for laboratory information system. 
수 있다[26-28](Figure 4). 국내에서는 국가진단검사 표준검사 실이 2011년 질병관리본부에 설치 운영되고 있다[29]. 표준검 사실이나 대한임상병리사협회에서 용혈 지수에 대한 표준측정 방법 또는 일차표준물질을 개발하여 표준화 작업한다면 혈청 지수에 대한 활용도가 더욱 높아질 수 있다고 생각된다.

본 연구는 많은 제한점을 가지고 있다. 첫째, 정확한 농도로 의 희석을 검증하기 힘들다는 것이다. 그러나 이를 극복하기 위 해 병원에 내원한 환자의 혈액 중에서 선택한 40 개의 SST 검체 를 통해 통계적으로 분석하였다. 둘째, CLSI EP07-A2에 따르 면 많은 내인성 또는 외인성 물질이 존재하고 분석에 따라 간섭 할 수 있다. 본 연구에서는 용혈에 인한 간섭 물질 이외에 다른 간섭 물질을 제한하지 않았다. 셋째, $\mathrm{BUN}$, creatinine, albumin, total cholesterol, ALT, ALP, total bilirubin, GGT, uric acid, calcium, amylase 종목들은 추정된 평균값보다 표 준편차가 크다. 이것은 임상 검사 종목이 작은 값을 갖는 가운데 용혈에 대한 변동에서 오는 백분율 차이가 크게 나타난 것이거 나 기기 간의 변동일 수 있다. 넷째, 본 연구에서 사용한 헤모글 로빈 측정 방법은 XE-2100 (Sysmex, Japan)의 SLS 방법으로 임상에서 쉽게 접근할 수 있고 비발암 물질이다. ICSH (International Council for Standardization in Hematology) 에서 권장하는 헤모글로빈 표준 측정방법인 시안화물 측정 방 법(cyanmethemoglobin method)은 헤모글로빈 변환 속도가 느리고 여러 단계의 변환 과정이 필요하고 발암 물질로 실험에 적합하지 않다 고려하였다. 헤모글로빈의 표준측정방법에 대 한 향후 논의가 필요하겠다.

본 연구를 통해 최선의 과학적인 근거를 위해서 용혈 지수와 혈청 헤모글로빈을 평가하여 정량적인 용혈의 기준값을 설정하 였다. 이를 통해 얻어진 결과를 용혈 거절의 기준을 만들어 실무 에서 근거중심 실무(practice of evidence based laboratory medicine)에 기여하고 일치화에 대한 기초자료로 활용되길 기 대한다.

\section{요 약}

용혈 지수(hemolysis index)는 생화학 장비에서의 용혈을 위한 반정량 지표이다. 용혈 지수의 특성이 상업 플랫폼마다 다 르기 때문에 용혈 지수의 표준화 또는 일치화는 현재 되어 있지 않다. 진단검사의학에서 일치화(harmonization)는 측정 절차 와상관없이 동일한 결과와 동일한 해석을 할 수 있는 능력을 말 한다. 임상 환자의 혈액 중에서 무작위로 추출한 40 개의 검체를 인위적으로 체외 용혈(in vitro hemolysis)시킨다. 혈액 자동화
장비인 XE-2100 (Sysmex, Japan)에서 측정된 혈청 헤모글로 빈을 기준으로 검체의 혈청을 $0 \sim 300 \mathrm{mg} / \mathrm{dL}$ 사이에서 20 $\mathrm{mg} / \mathrm{dL}$ 차이로 각각을 희석시킨다. 희석된 혈청 헤모글로빈을 생화학 자동화 장비 Hitachi-7600 (Hitachi, Japan)으로 측정 하여 용혈 지수와 혈청 헤모글로빈을 평가하였다. 용혈 지수와 혈청 헤모글로빈은 선형성을 보였으며 용혈 지수 1 은 대략 혈청 헤모글로빈 $20 \mathrm{mg} / \mathrm{dL}$ 정도였다. 용혈 거절 기준을 결정하기 위 해 용혈 지수를 세 그룹으로 나눈다: 용혈 지수 $0 ~ 1$, 용혈지수 4 6, 용혈 지수 9 15. 또 다른 임상 검체 40개의 검체를 Hitachi-7600 (Hitachi, Japan)로 각각의 임상 검사종목을 측 정한 후, 각각의 검체를 주사기의 피스톤을 앞- 뒤로 움직여 인 위적인 체외 용혈을 시키고 Hitachi-7600 (Hitachi, Japan)로 측정하였다. 세 그룹 사이의 임상 검사종목의 용혈로 인한 백분 율 차이(percentage difference)를 ANOVA 또는 KruskalWallis test 분석하였다. 사후 검정에서 용혈 지수 $0 \sim 1$ 인 그룹 과 용혈지수 5 6인 그룹 사이에 유의한 차이가 나는 종목들은 Glucose, creatinine, total protein, AST, direct bilirubin, uric acid, phosphorus, triglyceride, LDH, CPK, magnesium, potassium이였다. 많은 임상 검사 종목들이 용혈지수 4 6인 그룹과 참조 그룹인 용혈지수 $0 ~ 1$ 인 그룹 간에 통계적으로 유 의미한 차이를 보이기 때문에 용혈 기준은 대략 용혈지수 5 (혈 청 헤모글로빈 $100 \mathrm{mg} / \mathrm{dL}$ )가 적합하다 판단된다.

\section{Acknowledgements: None \\ Funding: None \\ Conflict of interest: None}

\section{REFERENCES}

1. Cho MS, Hwang MS. Factors affecting hemolysis in blood sampling and repeated sampling in the emergency department. J Korean Clin Nurs Res. 2011;17(3):399-410.

2. Carraro P, Plebani M. Errors in a stat laboratory: types and frequencies 10 years later. Clin Chem. 2007;53(7):1338-1342.

3. Lippi G, Blanckaert N, Bonini P, Green S, Kitchen S, Palicka V, et al. Haemolysis: an overview of the leading cause of unsuitable specimens in clinical laboratories. Clin Chem Lab Med. 2008;46(6):764-772.

4. Yanagisawa Y, Isobe K, Naito A, Ishijima M, Nanmoku T, Yamamoto T, et al. Influence of in vitro hemolysis on 80 different laboratory tests. Clin Lab. 2017;63(2):219-226.

5. Grant MS. The effect of blood drawing techniques and equipment on the hemolysis of ED laboratory blood samples. J Emerg Nurs. 2003;29(2):116-121.

6. Thomas L. Haemolysis as influence and interference factor. Biochim Clin. 2002;26(2):95-98. 
7. Dolci A, Panteghini M. Harmonization of automated hemolysis index assessment and use: is it possible? Clin Chim Acta. 2014; $432: 38-43$

8. Tate JR, Myers GL. Harmonization of clinical laboratory test results. EJIFCC. 2016;27(1):5-14.

9. Chakravarthy VK, Chandra DN, Prasanna BS, Rao M, Jaya T, Rao DR. Haemoglobin estimation by non-cyanide methods. J Clin Diagn Res. 2012;6(6):955-958.

10. Kwon YI. A review of the characteristics of early apparatus and methods for hemoglobin estimation. Korean J Clin Lab Sci. 2016; $48(4): 401-410$

11. Davis BH, Jungerius B. ICSH technical report 1-2009: new reference material for haemiglobincyanide for use in standardization of blood haemoglobin measurements. Int J Lab Hematol. 2010;32(2):139-141.

12. Lippi G, Luca Salvagno G, Montagnana M, Brocco G, Cesare Guidi G. Influence of hemolysis on routine clinical chemistry testing. Clin Chem Lab Med. 2006;44(3):311-316.

13. Lippi G. Chapter six-systematic assessment of the hemolysis index: pros and cons. Adv Clin Chem. 2015;71:157-170.

14. Petinos P. Laboratory management of haemolysed samples results of an RCPAQAP survey [Internet]. Australasia: RCPA; 2017 [cited 2017 September 18]. Available from: https://www. aacb.asn.au/documents/item/3438.1000_Laboratory_manageme nt_of_haemolysed_samples_results_of_an_RCPAQAP_survey_-_ Ms_Penny_Petinos.pdf.

15. Kang H. How to understand and conduct evidence-based medicine. Korean J Anesthesiol. 2016;69(5):435-445.

16. Frank JJ, Bermes EW, Bickel MJ, Watkins BF. Effect of in vitro hemolysis on chemical values for serum. Clin Chem. 1978; 24(11):1966-1970.

17. Lowe G, Stike R, Pollack M, Bosley J, O'brien P, Hake A, et al. Nursing blood specimen collection techniques and hemolysis rates in an emergency department: analysis of venipuncture versus intravenous catheter collection techniques. J Emerg Nurs. 2008;34(1):26-32.

18. Burns ER, Yoshikawa N. Hemolysis in serum samples drawn by emergency department personnel versus laboratory phlebotomists. Lab Med. 2002;33(5):378-380.

19. Sung YH, Hwang MS, Lee JH, Park HD, Ryu KH, Cho MS, et al. A comparison of the rates of hemolysis and repeated blood sampling using syringe needles versus vacuum tube needles in the emergency department. J Korean Acad Nurs. 2012;42(3):443-451.

20. Heyer NJ, Derzon JH, Winges L, Shaw C, Mass D, Snyder SR, et al. Effectiveness of practices to reduce blood sample hemolysis in EDs: a laboratory medicine best practices systematic review and meta-analysis. Clin Biochem. 2012;45(13):1012-1032.

21. Mccaughey EJ, Vecellio E, Lake R, Li L, Burnett L, Chesher D, et al. Current methods of haemolysis detection and reporting as a source of risk to patient safety: a narrative review. Clin Biochem Rev. 2016;37(4):143-151.

22. Petinos P, Gay S, Badrick T. Variation in laboratory reporting of haemolysis-a need for harmonisation. Clin Biochem Rev. 2015;36(4):133-137.

23. Park JG, Joo KW. Evaluation of interfering substances in routine chemistry tests using toshiba tba-c8000 chemistry analyzer. Korean J Clin Lab Sci. 2011;43(1):6-11.

24. Dimeski G, Clague AE, Hickman PE. Correction and reporting of potassium results in haemolysed samples. Ann Clin Biochem. 2005;42(2):119-123.

25. Lippi G, Luca Salvagno G, Blanckaert N, Giavarina D, Green S, Kitchen S, et al. Multicenter evaluation of the hemolysis index in automated clinical chemistry systems. Clin Chem Lab Med. 2009; 47(8):934-939.

26. Vermeer HJ, Thomassen E, de Jonge N. Automated processing of serum indices used for interference detection by the laboratory information system. Clin Chem. 2005;51(1):244-247.

27. Plebani M, Panteghini M. Promoting clinical and laboratory interaction by harmonization. Clin Chim Acta. 2014;432:15-21.

28. Price CP. Evidence-based laboratory medicine: is it working in practice? Clin Biochem Rev. 2012;33(1):13-19.

29. KCDC. Establishment of standardization system in national reference laboratory [Internet]. Cheongju: KCDC; 2017 [cited 2017 September 18]. Available from: https://www.gov.kr/portal/service/serviceInfo/PTR000051043. 